\title{
Sciences, knowledges, and the practice of forestry
}

\author{
Louise Fortmann $\cdot$ Heidi Ballard
}

Received: 9 October 2008/Revised: 10 April 2009/Accepted: 23 May 2009/Published online: 9 December 2009

(C) The Author(s) 2009. This article is published with open access at Springerlink.com

\begin{abstract}
We address the question of how credible knowledge that will contribute to more effective forest policy and management can be produced. We argue that some forest-related knowledge-producing practices of professional scientists and of local people are similar, and given the differences in the knowledge they produce, we explore how they might be used productively together to create better understandings of forests with resulting better forestry practice and policy. Using a case study of participatory forest ecology research, we demonstrate that when professional (conventional) scientists do research in collaboration with local experts (civil scientists), the resulting knowledge can be more accurate and more policy relevant than they could produce doing research on their own or only with other conventional scientists.
\end{abstract}

Keywords Non-timber forest products · Forest understory - Gaultheria shallon - Science and technology studies · Interdependent science $\cdot$ Civil science

This is one in a series of articles dedicated to Prof. Dr. Dr. h.c. Gerhard Oesten on the occasion of his 60th birthday.

Communicated by M. Moog.

L. Fortmann $(\bowtie)$

Department of Environmental Science, Policy and Management, University of California at Berkeley, Berkeley, CA, USA

e-mail: louise.fortmann@gmail.com

H. Ballard

School of Education, University of California at Davis, Davis, CA, USA

e-mail: hballard@ucdavis.edu

\section{Introduction}

Over the past half century, an epistemological shift has been taking place. For a very long period, the professional biophysical sciences were viewed as the primary, if not sole, means of producing accurate knowledge about the natural world, an iconic symbol of rationality and objectivity and a cornucopia of better human conditions (e.g., "better things for better living through chemistry" http://heritage.dupont. com/touchpoints/tp_1939/overview.shtml). That position has since been more critically examined. Objectivity is now understood to be socially constructed (Daston 1999), and the designation of scientific "facts" to be highly dependent on the networks to which their discoverers are connected, sometimes irrespective of their accuracy (Hacking 1999; Latour 1987). In the most extreme cases, the "miracles" of modern day science have proved to be the cause of human disease and ecological degradation. Consequently, more scholars have turned their attention to other knowledge production practices in order to broaden the sources and domains of knowledge from which solutions to environmental problems can be generated.

We address the question of how credible knowledge that will contribute to more effective forest policy and management can be produced. We argue that some forestrelated knowledge-producing practices of professional scientists and of local people are similar, and given the differences in the knowledge they produce, we explore how they might be used productively together to create better understandings of forests with resulting better forestry practice and policy. The practices that produce local forest knowledge include not just science, but also involve cultural heritage, emotion, art, and spiritual experiences. We recognize the importance of non-scientific sources of knowledge to certain understandings of forests and forest 
management practices (cf. Burnette and DeHose 2008). However, in this article, we focus on local knowledge production practices that are similar to professional science. To be clear, we are not arguing that all forms of producing knowledge locally constitute the practice of science, but rather, that overly narrow understandings of what does and does not constitute scientific practice have led to the detrimental exclusion of knowledge produced by local scientific practices from official forest management and forest policy. We propose an "interdependent science" in which "civil" and "conventional" scientists collaborate to address those questions of forest management and policy that neither scientific practice addresses adequately alone.

This article proceeds in four parts. First, we address conventional understandings of science and some of their critiques. Second, we propose a different understanding of science consisting of three categories of scientific practice: civil, conventional, and an emerging interdependent science, and apply them to forest science and the practice of scientific forestry, as defined in the following sections. Third, we provide a case study of conventional forest ecology research that was improved by using an interdependent science approach. Finally, we briefly discuss what it might take to institute interdependent science in the field of forest science and in the practice of scientific forestry.

\section{Conventional understandings of science and some critiques}

Our first step before exploring the potential contributions of different kinds of scientific knowledge production to forest management and policy must be to revisit the assumption that to be credible, knowledge-producing practices have to conform to what is understood to be the scientific method. Practices that do not conform to this method, particularly if they are not undertaken by credentialed professional scientists, are assumed not to be science, largely because only knowledge produced in this way is considered to be objective and therefore valid. ${ }^{1}$ Conant (1951:102) sums up the commonplace of this conventional view of science: "I have ventured to define science ... as that portion of accumulative knowledge in which new concepts are continuously developing from experiment and observation and lead to further experimentation and observation." As we shall show in the following text, Conant's definition is not particular to conventional science, but actually lies at the core of both civil and conventional science.

\footnotetext{
1 The view of those who make this argument as to what constitutes scientific method does not necessarily reflect the actual practice of science (cf. Latour 1987; Asquith 1996).
}

From the conventional point of view, science consists of creating generalizable knowledge (or, in some versions, discovering truth) through testing falsifiable hypotheses with empirical data collected through experimentation and/ or observation. Practitioners of the scientific method work to be as objective (or value-free) as possible, and focus on minimizing bias, though most are aware that eliminating all bias is impossible. In keeping with the principle of transparency, scientific data and methods are to be made available to others to test and replicate findings. Those who follow this view (both conventional scientists and policy makers as well as members of the public) believe that this specific form of research undertaken by specialized 'experts' is the primary, if not the only, source of information to guide policy. They deny, often explicitly, that other kinds of knowledge and the centuries of research done by people outside academia can inform policy and practice.

What is at stake in the debates over what constitutes science is the assignment of credibility to ways of producing knowledge and to people who may or may not be considered to be plausible knowledge-producers. Credibility is often aligned with social power. In this view, the powerful are designated as credible knowledge-producers and set the criteria for identifying who are other credible knowledge-producers. The powerless are not considered to be credible knowledge-producers (e.g., Daston 1999). People who do not have the right social markers (such as formal education, class, gender, and race) (Epstein 1995: 411) may be excluded from the category of credible knowledge-producers. People's ability to produce credible knowledge is dismissed because of who they are or are not (cf. Fricker 2007). If the knowledge they have produced is incorporated in scientific and policy debates, it is almost always mediated by those with the 'right' social markers. ${ }^{2}$

Primatologist and social theorist, Donna Haraway, and philosopher of science, Helen Longino, provide us with different lenses to look at and into science. Haraway defines the goal of science as 'better accounts of the world' (1999:182). Longino is more explicit about the necessity of science (2002:186), in defining the purpose of science as "...to understand the world around us, that is, the world we experience, and to interact with it successfully."

We find Haraway's (1999) concept of "situated knowledge" useful in demonstrating why the definition of credible knowledge-producers about forests should be extended beyond conventional forest scientists to include people with other kinds of forest knowledge. Haraway

\footnotetext{
${ }^{2}$ Sangtin and Nagar (2006) is a striking exception, although the academic press, in this case, did insist that the person with academic credentials (Richa Nagar) be named as an author separately from the other members of the writing collective.
} 
holds that all knowledge is created in a particular place, at a particular time, by a particular person (or people) who have specific social attributes. ${ }^{3}$ She argues against the conventional understanding of scientific objectivity, which she likens to a 'gaze from nowhere' (1999:176). She shows that acts of knowledge production are undertaken by people located specifically in time and space. That is, knowledge, including scientific knowledge, is produced by somebody whose endeavor to produce knowledge (say, by doing science) is affected by where (geographically, socially, and culturally) s/he is situated. Thus, all knowledge creation (including the production of scientific knowledge) is affected by social, spatial, and temporal context and all knowledge is, therefore, partial. From Haraway's viewpoint, privileging the partial knowledge produced by the scientific method is likely to preclude partial knowledge produced in other ways and therefore keep it from contributing to better accounts of the world. For example, Frickel and Vincent (2007) show in their analysis of the study of toxic contamination in the wake of Hurricane Katrina that professional scientists using scientific methods can foster ignorance through such practices as the use of scientifically accepted but nonetheless inappropriate tests.

\section{Three practices of scientific knowledge production}

We agree with Agrawal's (1995) argument that defining what he called indigenous knowledge and scientific knowledge as distinct phenomena is both misleading and runs counter to the interests of good science. We propose that instead of drawing a bright line around knowledge production practices conventionally known as science, we explore what they have in common with other knowledge production practices. In doing so, we have found it useful to think in terms of three interrelated practices of scientific knowledge production: conventional science, civil science, and interdependent science. ${ }^{4}$ What we are calling conventional science is commonly called professional science, western science, ${ }^{5}$ or science. What we call civil science is often referred to as indigenous knowledge, traditional ecological knowledge, local forest knowledge, as well as derogatory terms such as "barstool biology" (Robbins 2006). "Interdependent science" is a term coined by the

\footnotetext{
3 See also Longino (2002:9) who holds that all knowledge is not permanent but changes over time, provides only a partial understanding rather than a complete understanding of things, and takes many forms rather than a single form.

${ }^{4}$ For an earlier treatment of these concepts in the context of participatory research, see Fortmann (2008).

5 The term western science is misleading given the non-western origins of some contemporary science. See, for example, Grove (1995) and Needham (1954).
}

Zimbabwean anthropologist, Marshall W. Murphree (1997), to describe research conducted collaboratively by conventional and civil scientists. To our minds, both conventional and civil scientists are well equipped to answer certain kinds of questions independently. Other questions, however, are better addressed by the two working collaboratively in the form of interdependent science, especially when more effective forest practice and policy are at stake.

In the following, we do not attempt to re-plow the ground addressed in the huge literature that analyzes the norms, cultures, structures, and processes of various sciences. (In addition to sources cited in this article, see Merchant 1980; Cetina 1989; Martin 1991; Haraway 1997; Wyer et al. 2000; Thompson 2001.) Our furrow focuses on only a few characteristics of the approaches to science we address.

Conventional science is a set of knowledge-producing practices intended to provide, in Haraway's terms, better accounts of the world. Formally educated, conventional scientists almost always work in a professional organization using prescribed experimental and observational techniques, that is, the scientific method. Since it is their profession, their practice of science is likely to be continuous. Their science depends on access to networks of other conventional scientists, funds and funders, access to equipment and access to legitimizing institutions such as scholarly journals. Because of the social organization of conventional science, both conventional scientists and their findings travel with comparative ease. Their findings, which are validated institutionally by statistical tests, networks of other scientists and/or scholarly publications, are intended to be broadly generalizable. Because of this, however, they may not translate easily into useful solutions to local problems that may be very site specific. ${ }^{6}$

Civil science is also a set of knowledge-producing practices intended to provide better accounts of the world. Civil scientists may work collectively or alone, using experimental and observational techniques developed locally. They may practice science intermittently in order to solve specific problems as they arise. Their science depends on knowledge of local social-ecological relationships. The explicitly local, socially and ecologically embedded nature of civil science is its greatest strength as the answers to questions is often particular to context. Their concrete findings, which are validated by utility, are particular to a place but may be capable of being generalized, once context is taken into account. However, because civil science is likely to be a localized practice without formal institutional moorings, neither civil

\footnotetext{
${ }^{6}$ Scott (1998) asserts that 'practical knowledge' that is learned through practice is locally superior to general knowledge that often does not apply well to specific situations.
} 
scientists nor their findings travel far, if at all. On the other hand, because civil scientists emphasize utility and their practice is autonomous (that is, they are not subject to the national politics that affect formal scientific institutions), they may insist on and preserve good science when official institutions do not. For example, when in accordance with the genetics of Soviet scientist, T. D. Lysenko, the use of Chinese fir (Cunninghamia lanceolata) clones was discontinued under official Chinese (scientific) forest policy, peasant farmers in remote areas resisted the dictates of the state, protecting and continuing to use the clones, thus preserving them for use (Burdon and Libby 2006:15). The focus of civil science on contextualized (but possibly generalizable) utility resonates with Haraway's and Longino's definitions of science that can be taken as suggesting science is "for" something. People who are not paid to do science may do it because it can be useful for problem solving. It is also consistent with Scott's (1998:324) pithy observation that 'Unlike the research scientist or the extension agent who does not have to take her own advice, the peasant is the immediate consumer of his own conclusions.' When the information gatherers are the information users, the relevance of that information increases enormously for management and policy, as has long been known (Feldman and March 1981).

These are not, of course, static categories. The practices and social organization of both the civil and conventional sciences constantly change. In some documented cases, the organization of civil science is starting to look more like conventional science, as when civil scientists organize networks at multiple levels. In other cases, civil science has changed as civil scientists have come to use the tools of conventional science. For example, growing concern over the environment, particularly in Europe and the United States, has mobilized critiques of conventional scientific practice, at the same time disputing conventional scientific findings and gathering data to address problems at a more local scale. The use of conventional science data and practices has moved beyond credentialed scientists to civil scientists who see their own use of conventional science as part of a solution to their problems (Ballard et al. 2008). These civil scientists may become as specialized as credentialed conventional scientists (Latour 1987; Epstein 1995). In turn, in some cases, conventional science is in the process of change as some conventional scientists recognize the scientific value of the products of civil science, or what they are likely to call local knowledge (Briggs et al. 1998; Danielsen et al. 2005; Stephens 2008). In fact, the application of scientific knowledge in specific contexts may look very much like civil science as in the "work arounds" and "operational redesign" described in high reliability management professions by Roe and Schulman (2008).
Interdependent Science done collaboratively by local people and professional scientists can and has developed better understandings of conservation and of rural livelihoods. Interdependent science acknowledges that all people create knowledge, respects the knowledge and expertise of different kinds and classes of people, recognizes that effective research often requires multiple methods with which to triangulate on better practice, and evaluates and tests both conventional and civil science with equal rigor. In interdependent science, neither conventional science nor civil science is a handmaiden to the other.

For example, Ballard et al. (2008) studied seven community-based forestry groups in the United States that used both local ecological knowledge and conventional science to design or conduct ecological assessments, monitoring or research to inform their management. They found evidence, in the form of changes in attitudes on the part of local people and conventional scientists, and jointly produced reports, that the two types of knowledge were integrated by all groups. Rather than scientists and managers sprinkling local knowledge into their work as they saw fit, Ballard and her colleagues found numerous cases where scientists worked in partnership with local people to conduct monitoring and research. And rather than waiting for the conventional science to be sanctioned by or handed down from agencies or universities, some communitybased forestry groups hired scientists, trained local people and in other ways garnered conventional science for their own use (cf. also Belsky 2007).

Although it is beyond the scope of this article, we note that interdependent science will often require participatory methods. $^{7}$ Likewise, because interdependent science is locally embedded, the importance of and interrelationships between social and biophysical structures and processes may well generate transdisciplinary approaches. In more formal terms, the congruence of conventional and civil sciences rests on the fact that both look for and into patterns of evidence that must be interpreted — and shared —at some point case by case.

\section{Conventional and civil science in forestry}

These concepts better position us to understand how the practice of scientific forestry has relied on the knowledge produced by conventional science to the exclusion of civil science and why this matters for better forest management and policy. We start by addressing what are commonly (in the United States) called forest science (conventional science in our terminology) and local forest knowledge (or similar terms which in our terminology refer to the

\footnotetext{
7 On participatory research in forestry, see Slocum et al. (1995), David et al. (2006), Guijt (2007), Wilmsen et al. (2008).
} 
products of civil science) and their intersections with forest management.

In the United States, forest management practice by professional foresters is intended to be based on knowledge produced by conventional (forest) science and is generally referred to as scientific forestry. When using the term scientific forestry, we mean forest management practices fundamentally informed, if not determined by conventional forest science. Readers should not confuse the practice of scientific forestry with the practice of forest science. Nor should they assume that the brief history of scientific forestry presented here reflects, let alone encapsulates, the entire complex history of forest management or of forest sciences. 8

In the United States, scientific forestry is associated with the late nineteenth century and the German forester, Dietrich Brandis. Brandis introduced scientific forestry to the British colonial empire as well as to Gifford Pinchot, the founder of the US Forest Service (Balogh 2002). Professional foresters embraced scientific forestry for which conventional forest science was the source of objective knowledge about forests and the basis of acceptable forestry management practices (Dana and Fairfax 1980). In the minds of its practitioners, scientific forestry may be seen as the direct practical application of science and, therefore, to be associated with the privileged status of science. Needless to say, at least in the context of the United States, this can sometimes make the distinction between scientific forestry and conventional forest science rather murky. In order to avoid confusing terminology, we refer to the practitioners of scientific forestry [management] as professional foresters.

In the United States, scientific forestry defined the purpose of forestry as the efficient production of wood and fiber, with timber species as the object of its practice. In fact, Baker and Kusel (2003:48) assert that in the United States professional foresters considered the practice of forestry for any purpose other than timber production as "illegitimate." This meant that long-standing uses of forests such as grazing, non-timber forest products such as mushrooms and medicinals, and the intersection of these and other uses with agriculture (as in agroforestry ${ }^{9}$ ) were long defined as outside the bright line within which scientific forestry management and forest science took place.

\footnotetext{
${ }^{8}$ We emphasize that we are definitely not arguing that conventional forest science is without merit. One of us was, after all, educated as a conventional forest ecologist! We value all three forms of science depending on the circumstances.

${ }^{9}$ For example, when one of us joined the faculty of a university department of forestry, the librarian of the Forestry Library refused to accept the donation of a large collection of gray literature on agroforestry on the grounds that this was not part of the subject of forestry.
}

The segregation of forest science and scientific forestry from local management practices and civil (forest) science narrowed what both professional foresters and conventional (forest) scientists understood to be relevant to their professions, sometimes with adverse effect. Unsurprisingly then, many professional foresters and forest scientists have failed to recognize that forests also take forms such as fruit forests in, for example, Indonesia (Peluso 1996) and India (Govil personal communication n.d.) or agroforests (supporting livestock as well as timber and non-timber products) on almost every continent. Other critics argue that the focus on managing a few economically important species assumes that they (and other components of nature) "can be understood in isolation and manipulated without affecting other aspects of nature" (Bocking 2004:79), oversimplifying the landscape, ecosystems, and the people living there (Baker and Kusel 2003:148) (cf. also Scott 1998).

Some professional foresters have moved away from narrowly defined scientific forestry practices and beliefs. For example, in the United States where timber production on public lands has plummeted, forest managers are now called "vegetation managers," and are mandated to manage for wildlife, fuel reduction, and restoration. Other professional foresters still adhere to them. For example, during a forestry field trip in Sumatra in 1995, a professional Indonesian forestry officer looked with equanimity on a bare and ineptly harvested swath of former rainforest but pronounced his indignation and horror at a carefully tended forest of cinnamon trees that stabilized a steep hillside. Similarly in 2004, European foresters working on a carbon sequestration project in Uganda planted (without local consultation) exotic species with which they were familiar rather than indigenous species that were locally useful and more likely to survive through local care. Scientific forestry, in short, too often still trains a limited lens on local conditions and dismisses local knowledge produced by civil science as "unscientific and subjective" (Baker and Kusel 2003) and therefore of little, if any, use. ${ }^{10}$

The irony of this stance is that people's very dependence for their livelihood on natural resources and the ecosystems in which they are embedded can and often does promote the development of effective management practices and local ecological knowledge through civil science. The accuracy of knowledge produced by civil science has been

\footnotetext{
10 There are exceptions. For example, Gary Nakamura, a professional forestry extension worker in California, has worked with and, by his own statement, learned from Farrell Cunningham, a Mountain Maidu civil (forest) scientist (Middleton 2008). And even when the importance of local forest management systems have been scientifically documented, politics may prevent that knowledge from being incorporated into policy (Dove 1983). We thank an anonymous reviewer for bringing this article to our attention.
} 
repeatedly demonstrated for forestry on a case by case basis (e.g., Menzies 1994, 2007; Caniago and Siebert 1998; Sivaramakrishnan 1999; Baker and Kusel 2003). ${ }^{11}$ While such knowledge production is often popularly associated with indigenous communities resident in an area for centuries or longer, people who have resided for far shorter periods but who rely on forests for their livelihood have also been shown to have ecological knowledge that has informed conventional scientists (Ballard et al. 2008; Endress et al. 2004). The literature is also replete with arguments for integrating such local ecological knowledge production (civil science in our terms but not in theirs) with conventional science to achieve more generalizable sustainable resource management and biodiversity conservation and with wider demonstrations of its efficacy (Berkes et al. 2000; Folke et al. 1998; Gadgil et al. 1993; Sillitoe 1998; Pierotti and Wildcat 2000).

The training of professional foresters (and sometimes conventional scientists) may leave them with two blind spots. ${ }^{12}$ First, they are likely to underestimate significantly what local people know (and, by extension, the means by which they learn it). A clear example of the difference between what the professional foresters (or, by extension, conventional forest scientists) may think local villagers know and what those villagers actually do know is demonstrated by Nemarundwe and Fortmann (2008), who conducted research on woodland use and management in two rural villages in Zimbabwe with a research team of local villagers. The research team collected physical specimens of every species named in a stratified random sample survey of the uses of tree products. This required not only a detailed knowledge of the conditions in which each of the 122 tree species named in the survey grew and where they were located, but also the different names by which different villagers referred to the same tree species. Botanists in the National Herbarium in Harare examined the physical specimens and provided the Latin name of each species. In preparing for a village meeting at which the village team would present the research results, a professional forester revealed that he thought that the villagers used around five species of trees when, as noted earlier, they actually used 122 . Because of the emphasis on exotics in the scientific forestry training in Zimbabwe at the time, it is probable that this professional forester knew the names, uses, and ecological requirements of only a fraction of the indigenous species known and used by villagers.

\footnotetext{
11 Interdependent science is also being practiced in other fields with a management component such as plant breeding (Sperling et al. 2001, Witcombe et al. 2005), ecological restoration (Gross and HoffmannRiem 2005), and natural resource monitoring (Danielsen et al. 2009).

12 We do not yet know enough about civil scientists and their practices to identify their blind spots.
}

The second blind spot has roots in the successes (or apparent successes) of conventional science. The strongly held belief in the accuracy and efficacy of extant scientific forestry and conventional (forest) science has led to situations where professional foresters, or conventional (forest) scientists, or both, resist change as new data become available and the science itself begins to move on. ${ }^{13}$ For example, Sivaramakrishnan (1999) describes the struggles in the British colonial forest service over the exclusion of fire (an effective indigenous practice) from sal (Shorea robusta) and teak (Tectona Grandis) plantations in 19th century India and Burma. So powerful was their belief in the knowledge produced by conventional (forest) science and the scientific forestry management prescriptions based on that knowledge that a paper recommending the inclusion of fire was excluded from conference proceedings (Sivaramakrishnan 1999:239 (fn 75)).

Similar struggles took place within the US Forest Service when it abandoned its policy of total fire suppression to include prescribed burning. The agency's fire suppression icon, Smokey Bear, and the slogan "Only you can prevent forest fires" proved to have greater influence over some agency employees (and many members of the public) than the new conventional (forest) science-based policy. In the wake of the new understanding of the role of fire in forest ecosystems, the fires sweeping over western and southwestern United States almost every dry season (also known as fire season) are now popularly blamed on the fire suppression policy. The nuanced analyses of contemporary fire researchers (cf. Moritz and Stephens 2007) now note that in regard to fire "great local uncertainty exists for any given place" and suggest flexible fire policies and adaptive management programs "to allow for continued learning and evaluation" and "respond to complex social, political and economic forces." Clearly, this could provide an opportunity for the combination of conventional science and civil science in interdependent scientific research to develop the "adaptive" knowledge necessary to develop on-the-ground, case specific but possibly generalizable responses to local variability and uncertainty.

\section{Case study of interdependent science: ecological research with salal harvesters on the Olympic Peninsula, Washington, USA}

The following case study contrasts with the previous examples in which civil and conventional science and scientists were isolated from or working at odds with each other. Because the case represents interdependent science,

\footnotetext{
13 This is neither new nor restricted to forestry as Kuhn (1966) has shown.
} 
and given the importance of the evolving field to this article, the case is discussed at some length. We demonstrate how through observation and experimentation, floral greens harvesters (civil scientists) with minimal formal education produced knowledge and methods that were combined in a participatory research approach with knowledge and methods produced by a conventional (forest) scientist. This collaborative process constituted interdependent science with richer and more relevant and more valid findings than either could have produced alone.

Little is known about the ecological sustainability of NTFP (non-timber forest products) harvest in areas intensively managed for timber production where clearcutting is the predominant silvicultural practice. Whereas the ecological effects of NTFP harvest may be minimal compared to those of timber harvest, joint production of NTFPs with timber has the potential to provide economic incentives for forest managers to adopt management strategies that conserve biodiversity and other ecological values (Alexander et al. 2002; Kerns et al. 2003; Oliver and Larson 1996) and may be a strategy to more widely distribute the economic benefits of forest resources.

Salal (Gaultheria shallon Ericaceae), an evergreen shrub used in the floral industry, is one of the most widely harvested NTFP species in the Pacific Northwest, where the forests have been subject to clear-cut logging and even-age management practices since World War II (Haynes et al. 2003; Kohm and Franklin 1997). Because of its extensive cover and high frequency, salal is likely to exert a major effect on understory development (Huffman and Tappeiner 1997). Increased harvest intensity of salal in the last two decades has caused a marked decrease in the availability of commercial-quality salal in some areas according to harvesters and managers. Until recently, understory shrubs harvested as floral greens have been considered "weeds" in Pacific Northwestern forests under intensive timber management, so conventional scientific research on these species has been limited to their response to thinning, herbicides, and fertilizers (Bailey et al. 1998; He and Barclay 2000; Thomas et al. 1999). Although previous ecological research has been conducted on salal's response to timber management practices such as thinning and fertilizing, no scientific literature has been published on the effects of commercial harvest (Bunnell 1990; He and Barclay 2000).

Though NTFPs are generally used, managed, and conserved by local people, very few published extraction experiments have included the local knowledge or participation of local harvesters whose practices directly affect the resource (Ticktin 2004). Researchers who have involved harvesters in their research have found that resulting management recommendations for harvest regimes are more quickly implemented by local harvesters and more accurately reflect the local social and economic context in which harvest occurs (Endress et al. 2004; Ticktin and Johns 2002). However, here, we are not just arguing for the "improved adoption" of management practices by local people because of participation in research, but rather an integrated knowledge production that can be and has been locally applicable and (at least partially) generalizable.

To investigate the ecological impacts and sustainability of harvesting salal on a large commercial scale on the Olympic Peninsula, Ballard initially consulted other research ecologists in the area in an effort to develop a research project. Every ecologist and forest manager she met with, when pressed for detailed information, said, "Sorry, I don't know, you'd have to ask a harvester that question." This catalyzed the conversations with harvesters that would become a participatory research project on salal with harvesters who were members of the newly formed Northwest Research and Harvesters Association in Shelton, WA. It is important to note that the majority of salal harvesters are immigrants from Mexico and Central America, are often working in the United States illegally and many speak very little English. Despite their relatively short time living and working in the forests of the Olympic Peninsula (12 years or less), the harvesters working with Ballard had developed local ecological knowledge specific to salal harvest that was often greater than the forest professionals, and parallels what we usually think of as traditional ecological knowledge held by indigenous people (Ballard and Huntsinger 2006).

To understand the harvest and management of $G$. shallon on the Olympic Peninsula, Ballard collaborated with local harvesters in three ways. First, in the process of explaining harvest practices and management strategies, harvesters prompted Ballard to reframe her research question. Harvesters explained that if they would not likely return to an area, they would pick it differently than if they knew they would be able to pick there the following year. (Until she began collaborating with the harvesters, Ballard had assumed that sustainability of the salal harvest hinged on harvesting different commercial grades of salal.) Once she understood the importance of resource access, Ballard began collaborating with harvesters who helped redesign the research question such that the two harvest practices most often described were tested in the experiments. Harvesters defined one level of intensity (here called "Light Harvest") that is used primarily when they are certain of long-term ( 2 years or more) access to the land to harvest salal, and second level of intensity (here called "Heavy harvest") that is used primarily when access to the resource is uncertain or short-term only. Hence, the harvesters determined the specific questions regarding harvest intensity.

Second, salal harvesters participated in all aspects of the experimental design, including development of response 
variables used to measure impacts of harvest. Research site locations chosen by harvesters reflected the variety of environmental conditions in the area, such as differing elevations and forest stand types. Ballard and harvesters collaborated to design response variables in the plant's growth that would detect and measure more specifically impacts due to harvesting, such as percentage of leaves damaged by insects or fungi, and stem density of harvestable new shoots, variables not found in the literature. Ballard and the harvesters carefully defined which treatments to test based on the actual "Light" and "Heavy" harvest practices, combining actual harvesting practices with guidelines of biomass removal experiments. Ballard complemented the harvesters' expertise with statistically sound experimental design and plant ecology field methods, thus reflecting the multi-method, triangulatory approach of the participatory research. Because commercial characteristics involve more than just biomass, this study integrated growth response variables commonly used in forest understory studies to estimate growth and production with local harvesters' selection criteria (stem length and leaf condition) to define treatments. In this study, therefore, within a given treatment, the number of new shoots and biomass removed depended on the number of commercial quality shoots present, as occurs during actual harvest. This technique was also used by Endress et al. (2004) and proved a useful method of measuring effects of harvest as it really occurs.

The third way in which harvesters collaborated with Ballard on the project was on the design and implementation of the experimental harvest treatments. Harvesters helped to determine and apply the treatments, a Light Intensity (33\% removal) and Heavy Intensity (100\% removal) of the commercial-quality salal, by weighing and taking samples of the harvested product. Harvest techniques and intensity of removal were calibrated between harvesters in a neighboring stand. That is, for the first year's treatment, the research team discussed together what " $33 \%$ " and "100\%" of "available commercial product" looked like on plots outside the experiment site until everyone agreed on the treatment and how to apply it consistently. Much of the data collection was in Spanish on a data sheet translated from English to Spanish so that the Spanish-speaking harvesters ${ }^{14}$ could more readily participate. Throughout, Ballard found that explaining the scientific process in nontechnical language required her to be clearer about the focus of the research. For example, because commercial

\footnotetext{
${ }^{14}$ For more on role of migrants from Mexico and Central America in forestry in the United States, see Sarathy (2008) and Sarathy and Casanova (2008).
}

characteristics involve more than just biomass, the research team had to use more than the growth response variables commonly employed in forest understory studies to estimate growth and production. This study used local harvesters' selection criteria (stem length and leaf condition) to define treatments. This was in addition to measuring the percentage of biomass removed from total plant biomass as is typical, and is therefore fundamentally different from many other shrub defoliation studies (Huntsinger 1996; Tappeiner et al. 2001).

Fourth, the harvesters played a key role in interpreting the data. Ballard made bar graphs with the yield results for each experimental site each year. They analyzed why some results differed from their hypotheses, why sites responded differently to the same harvest treatments, and how the results could be used for management recommendations. The percentages of yield from the three sites of the experiment were so different that there was clearly an effect of site. A powerful explanation for this came from the harvesters. As part of the participatory research process, a group of about 25 harvesters gathered in the fall of 2003 to interpret the yield results as depicted in graphs of the three sites. They discussed how these compared to their observations in the field as well as what it might mean for management and harvest practices. Harvesters suggested that several factors might account for these results. The first year had been much wetter than the second year of the study (average precipitation $=165.5 \mathrm{~cm}$ in $2001,131.27 \mathrm{~cm}$ in 2002), and so the insect outbreaks were more severe in some areas than in others. This meant that some stands had salal that was very damaged by insect herbivory and so not commercially productive, whereas other sites produced well. This patchiness of insect damage could have occurred on the scale of the treatment areas as well, such that some areas were damaged and others were not, causing yields to appear counterintuitive in relation to previous years. Both of these point to design flaws and provided lessons as to how the two types of knowledge and science could have been even better integrated. In the future, replication of experimental blocks within each stand would provide greater statistical power regarding environmental factors such as insect outbreaks that affect commercial quality and consequently yield measures. Second, randomized treatments on smaller treatment areas more widely dispersed across a single stand would incorporate patchiness in insect and disease damage.

The benefits of harvester participation in the research consisted of more relevant new measures of commercial production, field-accurate harvest treatments applied by harvesters themselves, and experience-based interpretations of the results. The knowledge the harvesters brought to the interdependent scientific research had been developed through observation and experimentation, i.e., civil science. In the interdependent scientific research initiated 
by Ballard, her conventional scientific knowledge and methods were modified as a result of her collaboration with the harvesters and their civil scientific knowledge and methods. Harvesters developed their knowledge through a relatively short period (a decade or less) of intense interaction with the ecosystem. This demonstrates that like conventional science, civil science can be a short-term as well as a long-term practice.

Other recent studies have emphasized the importance of involving harvesters in experimental NTFP harvest research as this study does (Endress et al. 2004; Ticktin 2004). They conclude that results and sustainable management recommendations that come of participatory research are more likely to be endorsed and practiced by harvesters. The cost of using a participatory approach came in the form of fewer experimental sites, and also in the occasional difficulty in merging the harvester-defined treatments with more standardized ecological methods. Though replication for this experiment was fairly low (three experimental sites), and the length of time over which effects were measured was short $\left(2 \frac{1}{2}\right.$ years), the information gained about short-term impacts of harvesting salal at two different intensities has informed sustainable management of salal in Pacific Northwest forests, as well as informing future research on non-timber forest products in the region. None of this science would have been possible if the research had not been undertaken collaboratively.

\section{Conclusion}

We have demonstrated how the partial and situated knowledges commonly encompassed in the terms "scientific forestry" and "local forest knowledge" are better understood as having been produced by the practices of conventional and civil science. To put it differently, with the collaboration by both kinds of scientists, interdependent science can lead to more rigorous and relevant science. ${ }^{15}$ The evolving practice of interdependent science challenges the common scientific assumption that the conventional scientist (and, in the realm of management, the scientific forester) has expertise above and beyond any expertise or knowledge civil scientists (local residents) might produce. We emphasize that interdependent science is a grounded, ongoing, collaborative process, not a process of extracting and abstracting local knowledge for inclusion of the knowledge derived from civil science in databases (cf. Agrawal 2002 for a critique of such databases). Moreover, we believe that the case study illustrates that,

\footnotetext{
15 While recognizing the importance of basic and exploratory research, we note that when scientists are involved in problemsolving (applied research); there is generally little point in doing research that is absolutely precise and precisely irrelevant.
}

while focused on the local, interdependent science has the potential to establish best practices that extend across a range of other cases.

As forestry policy makers and forest managers come under increasing pressure to include local communities in decision-making, a process is needed by which scientists and local resource users can form partnerships in scientific research to inform that management (Getz et al. 1999). The processes of interdependent science illustrated here provide a possible model for doing this. This will require major changes in the education of conventional forest scientists and professional foresters just as it requires opening different kinds of educational opportunities and access to decision-making for civil scientists. First, since on-theground environmental problems are rarely just biophysical or just social, biophysical and social scientists need to learn to work in transdisciplinary ways. Second, since interdependent science almost always requires participatory methods, in order to do interdependent science effectively, conventional scientists need to learn (among other things) respect for knowledge produced by civil scientists, flexibility, humility, and the importance of long-term commitments to civil science colleagues. ${ }^{16}$ Finally, although the products of civil science are well known (albeit it not in those terms) particularly in rural development circles, much less is known about the practices of different kinds of civil scientists and how they might collaborate with conventional scientists. If interdependent science is to be developed and institutionalized, this is clearly an area for future research.

Acknowledgments We acknowledge the very helpful comments of Emery Roe, Achim Schlüter, and Roderich von Detten.

Open Access This article is distributed under the terms of the Creative Commons Attribution Noncommercial License which permits any noncommercial use, distribution, and reproduction in any medium, provided the original author(s) and source are credited.

\section{References}

Agrawal A (1995) Dismantling the divide between indigenous and scientific knowledge. Dev Change 26:413-439. doi:10.1111/ j.1467-7660.1995.tb00560.x

Agrawal A (2002) Indigenous knowledge and the politics of Classification. Int Soc Sci J 173:325-336

Alexander SJ, Pilz D, Weber NS, Brown E, Rockwell VA (2002) Mushrooms, trees, and money: value estimates of commercial mushrooms and timber in the Pacific Northwest. Environ Manage 30(1):129-141. doi:10.1007/s00267-002-2610-1

\footnotetext{
16 See Arora-Jonsson et al. (2008) for a longer treatment of what it would take to institutionalize interdependent science.
} 
Arora-Jonsson S et al (2008) Conclusions. In: Fortmann L et al (eds) Participatory research in conservation and rural livelihoods: doing science together. Blackwell, Oxford

Asquith PJ (1996) Japanese science and western hegemonies. In: Nader L (ed) Naked science: anthropological inquiry into boundaries, power and knowledge. Routledge, London, pp 240-256

Bailey JD, Mayrsohn C, Doescher PS, St. Pierre E, Tappeiner JC (1998) Understory vegetation in old and young Douglas-fir forests of Western Oregon. For Ecol Manage 112(2):289-302. doi:10.1016/S0378-1127(98)00408-3

Baker M, Kusel J (2003) Community forestry in the United States: learning from the past, crafting the future. Island Press, Covelo

Ballard HL, Huntsinger L (2006) Salal harvester local ecological knowledge, harvest practices and understory management on the olympic peninsula, Washington. Hum Ecol Interdiscip J 34(4):529-547. doi:10.1007/s10745-006-9048-7

Ballard HL, Fernandez-Gimenez ME, Sturtevant VE (2008) Integration of local ecological knowledge and conventional science: a study of seven community-based forestry organizations in the USA. Ecol Soc 13(2): 25

Balogh B (2002) Scientific forestry and the roots of the modern American State: Gifford Pinchot's path to progressive reform. Environ Hist

Belsky J (2007) Multi-party monitoring Holland Pierce HFRA Project. Community benefits: assessing USFS Outreach. Missoula, Montana: University of Montana. Unpublished report

Berkes F, Colding J, Folke C (2000) Rediscovery of traditional ecological knowledge as adaptive management. Ecol Appl 10(5):1251-1262. doi:10.1890/1051-0761(2000)010[1251: ROTEKA]2.0.CO;2

Bocking S (2004) Nature's experts: science, politics and the environment. Rutgers University Press, New Brunswick

Briggs J, Pulford ID, Badri M, Shaeen AS (1998) Indigenous and scientific knowledge: the choice and management of cultivation sites by Bedouin in Upper Egypt. Soil Use Manage 14:240-245

Bunnell FL (1990) Reproduction of salal (Gaultheria shallon) under forest canopy. Can J For Res 20(1):91-100. doi:10.1139/x90-013

Burdon RD, Libby WJ (2006) Genetically modified forests: from stone age to modern biotechnology. Forest History Society, Durham

Burnette B, DeHose J (2008) The land has wisdom. In: Fortmann L (ed) Participatory research in conservation and rural livelihoods: doing science together. Blackwell, Oxford

Caniago I, Siebert SF (1998) Medicinal plant ecology, knowledge and conservation in Kalimantan, Indonesia. Econ Bot 52(3):220-250

Cetina KK (1989) Epistemic cultures: how the sciences make knowledge. Harvard University Press, Harvard

Conant JB (1951) On understanding science: an historical approach. New American Library of World Literature Inc., New York

Dana ST, Fairfax SK (1980) Forest and range policy: its development in the United States. McGraw-Hill Book Company, New York

Danielsen F, Burgess ND, Balmford A (2005) Monitoring matters: examining the potential of locally-based approaches. Biodivers Conserv 14:2507-2542. doi:10.1007/s10531-005-8375-0

Danielsen F, Burgess ND, Balmford A, Donald PF, Funder M, Jones JPG, Alviola P, Balete DS, Blomley T, Brashares J, Child B, Enghoff M, Fjelds J, Holt AS, Ubertz HH, Jensen AE, Jensen PM, Massao J, Mendoza MM, Ngaga Y, Poulsen MK, Rueda R, Sam M, Skielboe T, Stuart-Hill G, Topp-JØrgensen E, Yonten D (2009) Local participation in natural resource monitoring: a characterization of approaches. Conserv Biol 1:31-42. doi: 10.1111/j.1523-1739.2008.01063.x

Daston L (1999) Objectivity and the escape from perspective. In: Biagioli $M$ (ed) The science studies reader. Routledge, New York, pp 110-123
David P, Ballard H, Jones ET (2006) Broadening participation in biological monitoring: handbook for scientists and managers. Pacific Northwest Research Station General Technical Report PNW-GTR-680

Dove M (1983) Theories of swidden agriculture and the political economy of ignorance. Agrofor Syst 1:85-99. doi:10.1007/ BF00596351

Endress BA, Gorchov DL, Peterson MB (2004) Harvest of the palm Chamaedorea radicalis, its effects on leaf production, and implications for sustainable management. Conserv Biol 18(3): 822-830. doi:10.1111/j.1523-1739.2004.00073.x

Epstein S (1995) The construction of lay expertise: AIDS activism and the forging of credibility in the reform of clinical trials. Sci Technol Hum Values 20:408-437

Feldman MS, March JG (1981) Information in organizations as signal and symbol. Adm Sci Q 26:171-186. doi:10.2307/2392467

Folke C, Berkes F, Colding J (1998) Ecological practices and social mechanisms for building resilience and sustainability. In: Berkes F, Folke C (eds) Linking social and ecological systems: management practices and social mechanisms for building resilience. Cambridge University Press, Cambridge, pp 414-436

Fortmann L (2008) Introduction: doing science together. In: Fortmann L (ed) Participatory research in conservation and rural livelihoods: doing science together. Blackwell, Oxford

Frickel Scott, Vincent B (2007) Katrina, contamination, and the unintended organization of ignorance. Technol Soc 29:181-188

Fricker M (2007) Epistemic injustice: power and the ethics of knowing. Clarendon Press, Oxford

Gadgil M, Berkes F, Folke C (1993) Indigenous knowledge for biodiversity conservation. Ambio 22:151-156

Getz WM, Fortmann L, Cumming D, du Toit J, Hilty J, Martin R, Murphree M, Owen-Smith N, Starfield AM, Westphal MI (1999) Sustaining natural and human capital: villagers and scientists. Science 283:1855-1856

Gross M, Hoffmann-Riem H (2005) Ecological restoration as a realworld experiment: designing robust implementation strategies in an urban environment. Public Underst Sci 14:269-284. doi: $10.1177 / 0963662505050791$

Grove RH (1995) Green imperialism: colonial expansion, tropical island Edens, and the origins of environmentalism, 1600-1860. Cambridge University Press, Cambridge

Guijt I (ed) (2007) Negotiated learning: collaborative monitoring in forest resource management. Resources for the Future, Washington

Hacking I (1999) The social construction of what? Harvard University Press, Cambridge

Haraway DJ (1997) Modest-Witness@Second-Millennium.FemaleMan-Meets-OncoMouse ${ }^{\mathrm{TM}}$ : feminism and technoscience. Routledge, London

Haraway DJ (1999) Situated knowledges: the science question in feminism and the privilege of partial perspective. In: Biagioli $\mathrm{M}$ (ed) The science studies reader. Routledge, New York, pp 172188 [1988]

Haynes RW, Monserud RA, Johnson AC (2003) Compatible forest management: background and context. Kluwer Academic Publishers, Dordrecht, The Netherlands

He F, Barclay HJ (2000) Long-term response of understory plant species to thinning and fertilization in a Douglas-fir plantation on southern Vancouver Island, British Columbia. Can J For 30:566572

Huffman DW, Tappeiner JCI (1997) Clonal expansion and seedling recruitment of Oregon Grape (Berberis nervosa) in Douglas-fir (Pseudotsuga menziesii) forests: comparisons with salal (Gaultheria shallon). Can J For Res 27(11):1788-1793. doi:10.1139/ cjfr-27-11-1788

Huntsinger L (1996) Grazing in a California silvopastoral system: effects of defoliation season, intensity, and frequency on 
deerbrush, Ceanothus integerrimus Hook. and Arn. Agrofor Syst 34(1):67-82. doi:10.1007/BF00129633

Kerns BK, Pilz D, Ballard H, Alexander SJ (2003) Compatible management of understory forest resources and timber. In: Monserud A, Haynes RW, Johnson AC (eds) Compatible forest management. Kluwer, Dordrecht

Kohm KA, Franklin JF (1997) Creating a forestry for the $21^{\text {st }}$ century: the science of ecosystem management. Island Press, Washington, D.C.

Kuhn TS (1966) The structure of scientific revolutions, 3rd edn. University of Chicago Press, Chicago

Latour B (1987) Science in action: how to follow scientists and engineers through society. Harvard University Press, Cambridge

Longino HE (2002) The fate of knowledge. Princeton University Press, Princeton

Martin E (1991) The egg and the sperm: how science has constructed a romance based on stereotypical male-female roles. Signs J Women Cult Soc 16:485-501. doi:10.1086/494680

Menzies NK (1994) Forest and land management in Imperial China. St. Martin's Press, New York

Menzies NK (2007) Our forest, your ecosystem, their timber: communities, conservation and the state in community-based forest management. Colombia University Press, New York

Merchant C (1980) The death of nature: women, ecology and the scientific revolution. Harper \& Row, New York

Middleton ER (2008) We were here, we are here, we will always be here: a political ecology of healing among the mountain Maidu. Unpublished $\mathrm{PhD}$ Dissertation, University of California at Berkeley

Moritz MA, Stephens SL (2007) Fire and sustainability: considerations for California's altered climate future. Clim Change 87(Suppl 1):265-271. http://www.springerlink.com/content/54 $11702235 \mathrm{mx} 5432 / \mathrm{p}=6 \mathrm{eb} 30 \mathrm{~d} 81535643 \mathrm{~d} 5831463712 \mathrm{db} 8 \mathrm{bcc} 9 \& \mathrm{pi}$ $=1$. doi:10.1007/s10584-007-9361-1

Murphree MW (1997). Interdependent science. Talk delivered to ESPM Colloquium, University of California at Berkeley

Needham J (1954) Science and civilisation in China volume I. Cambridge University Press, Cambridge

Nemarundwe N, Fortmann L (2008) Rediscovering participation: reflections on the Mhondoro tree study. In: Fortmann L (ed) Participatory research in conservation and rural livelihoods: doing science together. Blackwell, Oxford

Oliver CD, Larson BC (1996) Forest stand dynamics. John Wiley, New York

Peluso NL (1996) Fruit trees and family trees in an anthropogenic rainforest: property rights, ethics of access, and environmental change in Indonesia. Comp Stud Soc Hist 38(3):510-548

Pierotti R, Wildcat D (2000) Traditional ecological knowledge: the third alternative. Ecol Appl 10(5):1333-1340. doi:10.1890/ 1051-0761(2000)010[1333:TEKTTA]2.0.CO;2

Robbins P (2006) The politics of barstool biology: environmental knowledge and power in Greater Northern Yellowstone. Geoforum 37:185-199

Roe E, Schulman PR (2008) High reliability management: operating on the edge. Stanford University Press, Stanford

Sangtin W, Nagar R (2006) Playing with fire: feminist thought and activism through seven lives in India. University of Minnesota Press, Minneapolis
Sarathy B (2008) The marginalization of Pineros in the Pacific Northwest. Soc Nat Resour 21:671-686

Sarathy B, Casanova V (2008) Guest workers or unauthorized immigrants? The case of forest workers in the United States. Policy Sci 41:95-114

Scott JC (1998) Seeing like a state: how certain schemes to improve the human condition have failed. Yale University Press, New Haven

Sillitoe P (1998) The development of indigenous knowledge: a new applied anthropology. Curr Anthropol 39(2):223-252

Sivaramakrishnan K (1999) Modern forests: statemaking and environmental change in colonial eastern India. Stanford University Press, Palo Alto

Slocum R, Wichart L, Rocheleau D, Thomas-Slayter B (1995) Power, process and participation: tools for change. Intermediate Technology Publications, London

Sperling L, Ashby J, Smith ME, Weltzien RE, McGuire SS (2001) A framework for analyzing participatory plant breeding approaches and results. Euphytica 122(3):439-450

Stephens S (2008) Personal communication

Tappeiner JC, Zasada JC, Huffman DW, Ganio LM (2001) Salmonberry and salal annual aerial stem production: the maintenance of shrub cover in forest stands. Can J For Res 31(9):1629-1638

Thomas SC, Halpern CB, Flak DA, Liguori DA, Austini KA (1999) Plant diversity in managed forests: understory responses to thinning and fertilization. Ecol Appl 9(3):864-879

Thompson C (2001) When elephants stand for competing models of nature. In: Mol A, Law J (eds) Complexities: social studies of knowledge practices (Science and Cultural Theory). Duke University Press, Chapel Hill

Ticktin T (2004) The ecological implications of harvesting nontimber forest products". J Appl Ecol 41:11-21

Ticktin T, Johns T (2002) Chinanteco management of Aechmea magdalenae: implications for the use of TEK and TRM in management plans. Econ Bot 56(2):177-191

Wilmsen C, Elmendorf W, Fisher L, Ross J, Sarathy B, Wells G (eds) (2008) Partnerships for empowerment: participatory research for community-based natural resource management. Earthscan, London

Witcombe JR, Joshi KD, Gyawali S, Musa AM, Johansen C, Virk DS, Sthapit BR (2005) Participatory plant breeding is better described as highly client-oriented plant breeding. I. Four indicators of client-orientation in plant breeding. Exp Agric 41(3):299-319

Wyer M, Barbercheck M, Giesman D, Öztürk H, Wayne M (eds) (2000) Women, science and technology: a reader in feminist science studies. Routledge, London

Govil K (n.d.) Personal communication

\section{Web Sources}

http://heritage.dupont.com/touchpoints/tp_1939/overview.shtml, accessed 20 October 2007

http://www.smokeybear.com/news.asp accessed 16 March 2008 